J. Dairy Sci. 98:8775-8787

http://dx.doi.org/10.3168/jds.2015-9853

(C) American Dairy Science Association ${ }^{\circledR}, 2015$.

\title{
In vivo inhibition followed by exogenous supplementation demonstrates galactopoietic effects of prolactin on mammary tissue and milk production in dairy cows
}

\author{
V. Lollivier, ${ }^{*} † \ddagger$ P. Lacasse,§ J. Angulo Arizala,\# P. Lamberton, ${ }^{*} †$ S. Wiart, ${ }^{*} \dagger$ J. Portanguen, ${ }^{*} \dagger$ R. Bruckmaier, II \\ and $M$. Boutinaud ${ }^{*} \dagger^{1}$ \\ *INRA UMR1348 PEGASE, F-35590 Saint-Gilles, France \\ †INRA Agrocampus Ouest, UMR1348 PEGASE, F-35000 Rennes, France \\ ‡Université Européenne de Bretagne, F-35000 Rennes, France \\ §Dairy and Swine Research and Development Centre, Agriculture and Agri-Food Canada, 2000 College Street, Sherbrooke, Quebec, \\ Canada J1M 0C8 \\ \#Group GRICA, Faculty of Agricultural Science, University of Antioquia, AA 1226 Medellin, Colombia \\ IIVeterinary Physiology, Vetsuisse Faculty, University of Bern, CH-3012 Switzerland
}

\begin{abstract}
It has been previously shown that the long-term inhibition of milking-induced prolactin (PRL) release by quinagolide $(\mathrm{QN})$, a dopamine agonist, reduces milk yield in dairy cows. To further demonstrate that PRL is galactopoietic in cows, we performed a short-term experiment that used PRL injections to restore the release of PRL at milking in QN-treated cows. Nine Holstein cows were assigned to treatments during three 5-d periods in a $3 \times 3$ Latin square design: 1) QN: twice-daily i.m. injections of $1 \mathrm{mg}$ of QN; 2) QN-PRL: twice-daily i.m. injections of $1 \mathrm{mg}$ of QN and twice-daily (at milking time) i.v. injections of PRL ( $2 \mu \mathrm{g} / \mathrm{kg}$ body weight); and 3) control: twice-daily injections of the vehicles. Mammary epithelial cells (MEC) were purified from milk so that their viability could be assessed, and mammary biopsies were harvested for immunohistological analyses of cell proliferation using PCNA and STAT5 staining. In both milk-purified MEC and mammary tissue, the mRNA levels of milk proteins and $B A X$ were determined using real-time reverse-transcription PCR. Daily QN injections reduced milking-induced PRL release. The area under the PRL curve was similar in the control and PRL injection treatments, but the shape was different. The QN treatment decreased milk, lactose, protein, and casein production. Injections of PRL did not restore milk yield but tended to increase milk protein yield. In mammary tissue, the percentage of STAT5-positive cells was reduced during QN but not during QN-PRL in comparison with the control treatment. The percentage of PCNA-positive cells was
\end{abstract}

Received May 22, 2015.

Accepted June 29, 2015

${ }^{1}$ Corresponding author: Marion.Boutinaud@rennes.inra.fr greater during QN-PRL injections than during the control or QN treatment and tended to be lower during QN than during the control treatment. In milk-purified MEC, $\kappa$-casein and $\alpha$-lactalbumin mRNA levels were lower during QN than during the control treatment, but during QN-PRL, they were not different from the control treatment. In mammary tissue, the $B A X \mathrm{mRNA}$ level was lower during QN-PRL than during QN. The number of MEC exfoliated into milk was increased by QN injections but tended to be decreased by PRL injections. Injections of PRL also increased the viability of MEC harvested from milk. Although PRL injections at milking could not reverse the effect of $\mathrm{QN}$ treatment on milk production, their effects on cell survival and exfoliation and on gene expression suggest that the effect of QN treatment on the mammary gland is due to QN's inhibition of PRL secretion.

Key words: mammary gland, cell survival, cell differentiation, milk mammary epithelial cells, cell exfoliation

\section{INTRODUCTION}

Despite its etymology, where "pro" stands for before and "lact" stands for milk, prolactin (PRL) has not always been considered a galactopoietic hormone in ruminants. Although it has been well established in rodents and lagomorphs that PRL depletion reduces milk production, in ruminants the effects of PRL inhibition are less obvious, and the galactopoietic role of PRL has been a matter of debate for several decades (Knight, 2001). Several of the present authors recently showed that the long-term inhibition of PRL with a potent dopamine agonist, namely quinagolide $(\mathbf{Q N})$, reduced milk yield in dairy cows (Lacasse et al., 2011). However, a complete demonstration of the galactopoietic role of 
PRL in ruminants requires showing that the effect of QN on the mammary gland is due to the inhibition of PRL secretion.

The actions of PRL on mammary epithelial cells (MEC) have been described in rodent cell lines and in primary bovine MEC cultures. The signaling of PRL begins with the binding to 1 of 2 forms of PRL receptors (PRLR): long and short isoform. After inducing the dimerization of the long isoform of its receptor, PRL signaling is followed by the activation by phosphorylation of both its receptor and the protein tyrosine kinase JAK2, which in turn phosphorylates the signal transducer and activator of transcription STAT5. Once activated, STAT5 translocates to the nucleus and binds to specific regulatory sites in the promoters of target genes such as milk protein genes (Groner and Gouilleux, 1995). Also in primary bovine MEC cultures, PRL has been shown to upregulate the mRNA levels of several caseins (Choi et al., 1988). A high number of other genes are under the control of PRL stimulation, as has been shown in bovine MEC using microarray analyses (Stiening et al., 2008; Riley et al., 2010). In association with its role in MEC differentiation, PRL is also known to promote DNA synthesis and cell proliferation, as has been demonstrated in rabbit and bovine MEC (Suard et al., 1983; Olazabal et al., 2000). Thus, one way to demonstrate that the effect of QN on the mammary gland is related to its inhibition of PRL is to analyze the effects of QN treatment at the level of MEC differentiation and proliferation and the activation of STAT5, which are known to be modulated by PRL in vitro.

Some previous studies have attempted to analyze the effect of PRL in dairy ruminants via PRL injections. The short-term administration of exogenous PRL did not significantly affect the milk yield of dairy cows during the first 3 wk of lactation (Wall et al., 2006) or around peak of lactation (Plaut et al., 1987). Even though the galactopoietic role of PRL in lactating sows is well established, PRL failed to stimulate milk yield in that species (Farmer et al., 1999). Because milkinginduced PRL release decreases as lactation advances (Koprowski and Tucker, 1973), early in lactation, endogenous PRL is secreted at relatively high levels in response to milking, and thus the mammary gland may already be saturated. The effect of endogenous PRL on mammary tissue could prevent the action of exogenous PRL on milk production. Therefore, the injection of exogenous PRL in a later lactation stage may be a more efficient way to affect milk production. Moreover, so that interaction with endogenous PRL can be avoided, a replacement therapy study may be a more efficient way to demonstrate the role of PRL in mammary tissue. Thus, to assess the galactopoietic role of PRL and the specific action of PRL in the mammary tissue of dairy cows, we inhibited its secretion using QN treatment and tried to restore milking-induced PRL release using a recombinant bovine PRL injection.

\section{MATERIALS AND METHODS}

\section{Animals and Experimental Design}

All the procedures applied to animals were approved by the Animal Care Committee of the French Ministry of Agriculture, in accordance with French regulations (decree no. 2001-464, May 26, 2001). The cows were housed at the INRA Méjusseaume experimental dairy farm, (Le Rheu, France). Cows were all managed in individual tie stalls.

Nine multiparous Holstein cows $(620 \pm 79 \mathrm{~kg}$ of BW) at $90 \pm 12$ DIM were randomly assigned to treatments during three 5 -d periods according to a $3 \times 3$ Latin square design balanced for residual effects (Cochran and Cox, 1957). Each 5-d experimental period was separated from the next by $9 \mathrm{~d}$ of rest without treatment. The 3 treatments were as follows: 1) QN: twice-daily i.m. injections of $1 \mathrm{mg}$ of QN (Ferring, Wallisellen, Switzerland); 2) QN-PRL: twice-daily i.m. injections of $1 \mathrm{mg}$ of $\mathrm{QN}$ and twice-daily (at milking time) i.v. injections of bovine PRL (HMC, Torrance, CA) at 2 $\mu \mathrm{g} / \mathrm{kg}$ of $\mathrm{BW}$; or 3 ) control: twice-daily injections of the vehicles. Quinagolide was diluted at $1 \mathrm{mg} / \mathrm{mL}$ in sterile water, mixed with a magnetic stir bar for 5 min, and then sonicated for $45 \mathrm{~min}$ at room temperature. Prolactin was first diluted in $\mathrm{NaCO}_{3}, 0.01 \mathrm{M}$, and then diluted 50:50 in physiological saline. Quinagolide or water injections were given 30 min before each milking (2 milkings per day) for $5 \mathrm{~d}$ in each experimental period, whereas exogenous PRL at $0.67 \mathrm{mg} / \mathrm{mL}$ or saline buffer was given through a catheter at each milking. One cow was withdrawn for health reasons from the experiment during the last period, but her data from the other periods were included in the analysis.

The cows were milked twice a day at 0715 and 1715 h. They were fed ad libitum according to INRA guidelines. The cows were fed ad libitum a diet containing (on a DM basis) $59.4 \%$ corn silage, $5.7 \%$ dry hay, $20.9 \%$ corn grain, $13.2 \%$ formaldehyde-treated soybean meal, $12.9 \%$ nonmineral supplement, $8.6 \%$ dehydrated alfalfa, $3.9 \%$ soybean meal, and $1.9 \%$ mineral supplement. The total mixed ration was formulated to meet the energy requirement $\left(\mathrm{NE}_{\mathrm{L}}=1.6 \mathrm{Mcal} / \mathrm{kg}\right.$ of $\left.\mathrm{DM}\right)$ and to be above the MP requirement (i.e., PDI for protein digestible in the intestine in the French system with PDI = $110 \mathrm{~g} / \mathrm{kg}$ of DM) in the control treatment according to INRA (2007). Feed intake and milk production were recorded daily during the treatment period. The cows 
were surgically equipped with a permanent catheter inserted in a jugular vein the day before the first blood sampling, and the catheter remained there for the duration of the study, as described previously (Lacasse et al., 2011).

During the experimental period, milk samples were collected at every morning and afternoon milking for the determination of milk fat content, protein content, and SCC using an infrared method (Lillab, Châteaugiron, France). At the morning milking on d 4 of each period, additional milk samples were collected. Milk lactose was analyzed by means of a colorimetric enzymatic reaction (kit for lactose/D-galactose; Roche Diagnostics, Meylan, France) using a multiparameter analyzer (KONE Instruments Corp., Espoo, Finland). The milk samples from d 4 of the experimental periods were also used to analyze total $\mathrm{N}$ content (Kjeldahl method), nonprotein $\mathrm{N}$ content (precipitation at $\mathrm{pH}$ 4.6 with TCA and filtration), and noncasein $\mathrm{N}$ content (precipitation at $\mathrm{pH} 4.6$ with $10 \%$ acetic acid and 1 $M$ sodium acetate). Casein was determined as total $\mathrm{N}$ minus noncasein $\mathrm{N}$, and whey protein was determined as noncasein $\mathrm{N}$ minus nonprotein $\mathrm{N}$.

\section{Determination of Milking-Induced Prolactin Release and Plasma Metabolite Concentrations}

On d 4 of each period, samples were taken during the morning milking at $-15,-2,1,2,4,6,8,15$, and $20 \mathrm{~min}$ relative to milking-unit attachment, using Monovette syringes coated with sodium heparin (Sarstedt, Nümbrecht, Germany). Plasma was separated by centrifugation at $4^{\circ} \mathrm{C}$ and $3,000 \times g$ for $15 \mathrm{~min}$ and then stored at $-20^{\circ} \mathrm{C}$ until subsequent analysis. Plasma PRL concentrations were measured using an indirect competitive ELISA (Lacasse et al., 2011). Intraassay variability was less than $2 \%$, and interassay variability was less than $12 \%$. The basal PRL concentration was determined as the PRL concentration in plasma at -2 min relative to milking-unit attachment, the PRL peak concentration was determined as the maximum PRL concentration in plasma during the first $20 \mathrm{~min}$ following milkingunit attachment, and the PRL delta was determined as the difference between the peak and basal values. The amounts of PRL released into the blood at milking were calculated by determining the areas under the curves (AUC) of PRL concentration during the first 20 min following milking-unit attachment.

Additional plasma samples were collected at -2 , $1,2,4,6,8$, and $15 \mathrm{~min}$ relative to milking-unit attachment with EDTA-coated tubes (Sarstedt) for the determination of blood growth hormone concentration by RIA (Hammon and Blum, 1997). Other additional plasma samples were collected with heparin-coated tubes and EDTA-coated tubes (Sarstedt) 25 min after milking-unit attachment at the morning milking on $\mathrm{d} 4$. Concentrations in plasma (from heparin-coated tubes) of glucose, urea, NEFA, and lactose were measured on a multiparameter analyzer (KONE Instruments Corp.). Commercial kits for glucose (glucose hexokinase kit; Roche Diagnostics), NEFA (NEFA C test; Wako Diagnostics, Oxoid, Dardilly, France), urea (ref. 11703; Thermo Electron, Cergy-Pontoise, France), and lactose (kit for lactose/D-galactose; Roche Diagnostics) were used. Concentrations in plasma (from EDTA-coated tubes) of IGF-1 were determined by RIA (Hammon and Blum, 1997).

\section{Milk Mammary Epithelial Cell Preparation}

On d 4 of each period, milk samples were collected at morning milking for MEC purification, as previously described (Boutinaud et al., 2008) with some modifications. Fresh milk $(1.6 \mathrm{~L})$ was centrifuged at $1,500 \times g$ and $4^{\circ} \mathrm{C}$ for $15 \mathrm{~min}$. The fat layer and the skim milk were discarded, and the cell pellet was retained. The cell pellet was suspended in PBS. After 2 washes in PBS, the cell pellet was resuspended in $1 \mathrm{~mL}$ of PBS containing $1 \%$ BSA. A $10-\mu \mathrm{L}$ volume of this cell suspension was analyzed using a Vi-CELL XR cell counter (Beckman Coulter, Roissy, France) to determine the total milk cell count and cell viability. A $240-\mu \mathrm{L}$ volume of magnetic beads (Pan Mouse IgG, Dynal Biotech, Invitrogen, Cergy-Pontoise, France) was incubated with $4.9 \mu \mathrm{L}$ of anti-human cytokeratin high-molecular-weight antibody (M0630, Clone 34ßE12, Dako, Trappes, France) in 1 $\mathrm{mL}$ of $1 \%$ PBS-BSA for immunocytochemical binding of MEC. Each cell sample was incubated with $100 \mu \mathrm{L}$ of the bead-antibody mix described above. After $1 \mathrm{~h}$ of incubation, the samples were placed in a magnetic particle concentrator (MPC-S; Dynal Biotech, Invitrogen), and the supernatant containing nonselected cells was removed. The purified MEC were resuspended in $1 \mathrm{~mL}$ of $1 \%$ PBS-BSA. A $20-\mu \mathrm{L}$ aliquot of purified cell suspension was collected for a hemocytometer cell count using a KOVA Glasstic Slide (Hycor Biomedical Ltd., Penicuik, UK) and for determination of cell viability using a Vi-CELL XR analyzer (Beckman Coulter). The MEC were pelleted by centrifugation $(5,000 \times g, 5 \mathrm{~min}$, $4^{\circ} \mathrm{C}$ ), and $1 \mathrm{~mL}$ of TRIzol (Invitrogen) was added. The milk MEC samples were mixed, and the lysates were stored at $-80^{\circ} \mathrm{C}$ until RNA extraction.

\section{Mammary Biopsies}

Mammary biopsies were collected before afternoon milk collection on d 5 of the treatment periods. Biopsies 
were taken, as previously described (Boutinaud et al., 2012), from the upper portion of the mammary gland using the $70 \times 4$-mm instrument described by Farr et al. (1996). Biopsies were harvested from the same site alternating right and left rear glands between periods.

Mammary tissue was rinsed in sterile saline solution to remove all traces of blood and then cut into 2 parts. One part was immediately frozen in liquid nitrogen and then stored at $-80^{\circ} \mathrm{C}$ for separate analyses of RNA. The other part was washed in PBS and fixed in $4 \%$ paraformaldehyde for immunohistochemistry. The fixed tissue was cryoprotected by incubation for $48 \mathrm{~h}$ in a $40 \%$ sucrose-PBS solution, embedded in Tissue-Tek O.C.T. compound (Sakura Finetek Europe, LaboNord, Templemars, France), frozen in a cooled bath of isopenthane (Sigma-Aldrich, Lyons, France), and stored at $-80^{\circ} \mathrm{C}$ until use.

\section{Immunohistochemistry for Apoptotic, PCNA- Positive, and STAT5-Positive Cell Detection in Mammary Tissue Sections}

The determination of the percentage of apoptotic cells in the mammary gland biopsy sections was based on DNA fragmentation detection using terminal deoxynucleotidyl transferase-mediated dUTP nick-end labeling (TUNEL) staining, as previously described (Boutinaud et al., 2012). Proliferating mammary cells were identified as cells expressing the proliferating cell nuclear antigen (PCNA), as previously described (Boutinaud et al., 2012). To detect STAT5-positive cells, mammary gland cryosections measuring $7 \mu \mathrm{m}$ thick were permeabilized in PBS with $0.05 \%$ saponin, $2 \% \mathrm{BSA}$, and $0.05 \%$ sodium azide for $1 \mathrm{~h}$ at room temperature and then labeled as previously described in goat mammary tissue (Boutinaud and Jammes, 2004). After TUNEL, PCNA, or STAT5 labeling, the sections were incubated for 3 min with 4',6-diamidino-2-phenylindole (DAPI; Sigma-Aldrich) at a concentration of $0.33 \mu \mathrm{g} / \mathrm{mL}$. All slides were mounted with Vectashield (Valbiotech, Paris, France) and examined under fluorescence using a Nikon Eclipse E400 microscope (Nikon France, Le Pallet, France). The images were captured with a DXM 1200 digital still camera (Nikon France) and analyzed with the ImageJ software (W. Rasband, National Institutes of Health, Bethesda, MD). Eight microscopic fields (magnification, 200×; area, $0.14 \mathrm{~mm}^{2}$ per microscopic field) were examined for each staining. The automatic detection for PCNA, STAT5, and DAPI staining allows the detection of nuclear staining only, taking into account the size of the automatic figures counted and rejecting the figures with a low size. The percentages of apoptotic, PCNA-positive, and STAT5- positive cells in mammary tissue were each determined as a ratio between the TUNEL-, PCNA-, or STAT5labeled cells and DAPI-counterstained nuclei.

\section{RNA Extraction}

The RNA was extracted with TRIzol (Life Technologies, Saint Aubin, France) from both mammary biopsy samples and milk-purified MEC samples and then purified using the column from the RNeasy Mini Kit (Qiagen, Courtaboeuf, France) according to the manufacturer's recommendations, including the DNase digestion. The RNA pellet was suspended in RNase-free water, and the amount of total RNA was determined with an Agilent 2100 bioanalyzer (Agilent Technologies, Massy, France). The RNA quality was assessed using the RNA integrity number generated by version B.02 of the Agilent 2100 expert software (Agilent Technologies). Three RNA samples from milk-purified MEC were eliminated from the analysis because of their poor RNA quality.

\section{Real-Time Reverse-Transcription PCR}

Total RNA from mammary tissue and milk purified MEC was used for real-time reverse-transcription PCR (RT-qPCR) analyses. Complementary DNA was obtained in $10 \mu \mathrm{L}$ of reaction buffer using the First Strand cDNA kit (Promega, Lyon, France) according to the manufacturer's instructions, from 500 and $200 \mathrm{ng}$ of total RNA for mammary tissue and milk-purified MEC samples, respectively. Reverse-transcription products were diluted by a factor of 50. Real-time PCR (qPCR) was performed using SYBR Green Master Mix (Applied Biosystems, Villebon-sur-Yvette, France) according to the manufacturer's instructions. Briefly, $2.5 \mu \mathrm{L}$ of cDNA was mixed with 6 pmol of all forward and reverse primers and adjusted to $12.5 \mu \mathrm{L}$ with SYBR Green Master Mix and $10 \mu \mathrm{L}$ of DNase-free water. The qPCR amplification cycle consisted of 2 min of incubation at $50^{\circ} \mathrm{C}$ followed by denaturation for $10 \mathrm{~min}$ at $95^{\circ} \mathrm{C}$ and 40 cycles of denaturation for $15 \mathrm{~s}$ at $95^{\circ} \mathrm{C}$ and annealing/extension for $60 \mathrm{~s}$ at $60^{\circ} \mathrm{C}$. Finally, a dissociation step was performed, involving a linear increase of $1^{\circ} \mathrm{C} / \mathrm{min}$ from 60 to $95^{\circ} \mathrm{C}$ with continuous fluorescence acquisition. The $\mathrm{qPCR}$ reactions on each sample were performed in triplicate. The PCR amplifications were performed using the primers for cyclophilin (PPIA), $R 18 S, G A P D H$, ribosomal protein large P0 (RPLPO), $\alpha$-lactalbumin $(\boldsymbol{L} \boldsymbol{A} \boldsymbol{L} \boldsymbol{B} \boldsymbol{A})$, and $\kappa$-casein (CSN3), Ecadherin (CDH1), BAX, Bcl2, and PRLR long isoform and short isoform, as previously described (Boutinaud et al., 2008, 2012; Ben Chedly et al., 2009). The number 
of amplified mRNA molecules was determined as previously described (Boutinaud et al., 2004), according to the following formula:

$$
\mathrm{Nb} \mathrm{Mol}=10^{(\mathrm{Ct}-40) / \mathrm{S}},
$$

where $\mathrm{Nb} \mathrm{Mol}$ is the approximate number of mRNA molecules, Ct is the average cycle threshold for PCR triplicates of a considered gene, and $\mathrm{S}$ is the slope of the calibration curve performed using serial cDNA dilutions of the same sample.

The calibration curves were generated for each target and housekeeping gene using serial dilutions of a reference mammary tissue cDNA sample from a lactating $\operatorname{cow}(1: 10,1: 20,1: 50,1: 100,1: 200,1: 1,000$, and 1:2,000). A nontemplate negative control was incorporated in all PCR runs.

The PPIA, R18S, GAPDH, and RPLP0 genes were evaluated as potential reference genes. The GeNorm (Vandesompele et al., 2002) and NormFinder (Andersen et al., 2004) programs were used to assess the variability of candidate reference genes. The gene with the most stable expression was PPIA, and it was therefore used as the reference gene during this study. The results for each target gene are expressed as ratios using the selected reference gene, namely PPIA.

\section{Statistical Analyses}

Variables with more than one value per period (milk production and composition, hormone and metabolite concentrations) were averaged per period and the obtained mean values used in the statistical analysis. Each parameter was analyzed by the method of least squares ANOVA using the general linear model procedures in the epsilon Windows software (L. Delaby, UMR PEGASE, Saint-Gilles, France) according to the following statistical model:

$$
\begin{gathered}
\mathrm{Y}_{\mathrm{ijk}}=\mu+\text { COW }_{\mathrm{i}}+\text { PERIOD }_{\mathrm{j}} \\
+ \text { TREATMENT }_{\mathrm{k}}+\mathrm{e}_{\mathrm{ijk}},
\end{gathered}
$$

with COW, PERIOD, and TREATMENT (control, QN, and QN-PRL) considered as a fixed effect. The results were expressed as least squares means with SEM. Differences among treatments were compared 2 by 2 using a $t$-test and using 2 orthogonal contrasts. The first contrast was used to test the effect of PRL injections by comparing the effect of the QN treatment to the effect of QN-PRL. The second contrast was used to test the effect of QN injections by comparing the effect of the control treatment to the effect of QN + QN-PRL. The results were expressed as LSM with the highest SEM. The mRNA and histological data were transformed to $\log _{10}$ before the statistical analyses. Pearson correlation coefficients were determined among the data. Statistical significance was set at $P \leq 0.05$, and tendency was set at $0.05<P \leq 0.10$.

\section{RESULTS}

The basal PRL concentrations before milking were similar among the treatments (Table 1). The amount of PRL (AUC of the first 20 min) released at milking was greatly reduced during the QN treatment $(P<0.05$; Table 1) in comparison with the amount released during the control or QN-PRL treatment. The amount of PRL after PRL injections was similar to the amount of endogenous PRL released at milking $(P=0.54$; Figure 1 and Table 1). However, the shape of the curve was different, with a narrower peak of PRL in the blood for QN-PRL (Figure 1). Indeed, the concentration of PRL was already at the maximum at the first sampling after milking-unit attachment (1 min) during QN-PRL, whereas the peak PRL concentration occurred at $4 \mathrm{~min}$ during the control treatment (Figure 1). In addition,

\begin{tabular}{|c|c|c|c|c|c|c|c|}
\hline Item & \multicolumn{3}{|c|}{ Treatment } & SEM & $P$-value & \multicolumn{2}{|c|}{ Contrast } \\
\hline $\mathrm{AUC}(\mathrm{ng} \cdot \mathrm{min} / \mathrm{mL})$ & $24,340^{\mathrm{a}}$ & $1,760^{\mathrm{b}}$ & $20,070^{\mathrm{a}}$ & 3,808 & 0.002 & 0.004 & 0.008 \\
\hline Delta (ng/mL) & $34.6^{\mathrm{a}}$ & $1.0^{\mathrm{b}}$ & $52.8^{\mathrm{a}}$ & 8.12 & 0.002 & 0.001 & 0.424 \\
\hline Basal (ng/mL) & 15.4 & 14.0 & 13.9 & 1.58 & 0.73 & 0.97 & 0.44 \\
\hline
\end{tabular}

Table 1. Milking-induced prolactin release in the plasma of cows injected with the vehicles (control), quinagolide (QN), or quinagolide plus prolactin (QN-PRL; $\mathrm{n}=26)^{1}$

${ }^{\mathrm{a}, \mathrm{b}}$ Letters indicate significant difference according to the treatments.

${ }^{1} \mathrm{QN}=1 \mathrm{mg}$ of quinagolide was injected i.m. twice a day $30 \mathrm{~min}$ before milking. PRL $=$ prolactin at $2 \mu \mathrm{g} / \mathrm{kg}$ of BW was injected i.v. twice a day at milking time. AUC = area under the curve of prolactin concentration in plasma during the first 20 min following milking-unit attachment. Peak $=$ maximum prolactin concentration in plasma during the first 20 min following milking-unit attachment. Delta $=$ difference between peak and basal values. Basal $=$ prolactin concentration in plasma before milking-unit attachment $(-2 \mathrm{~min})$. 


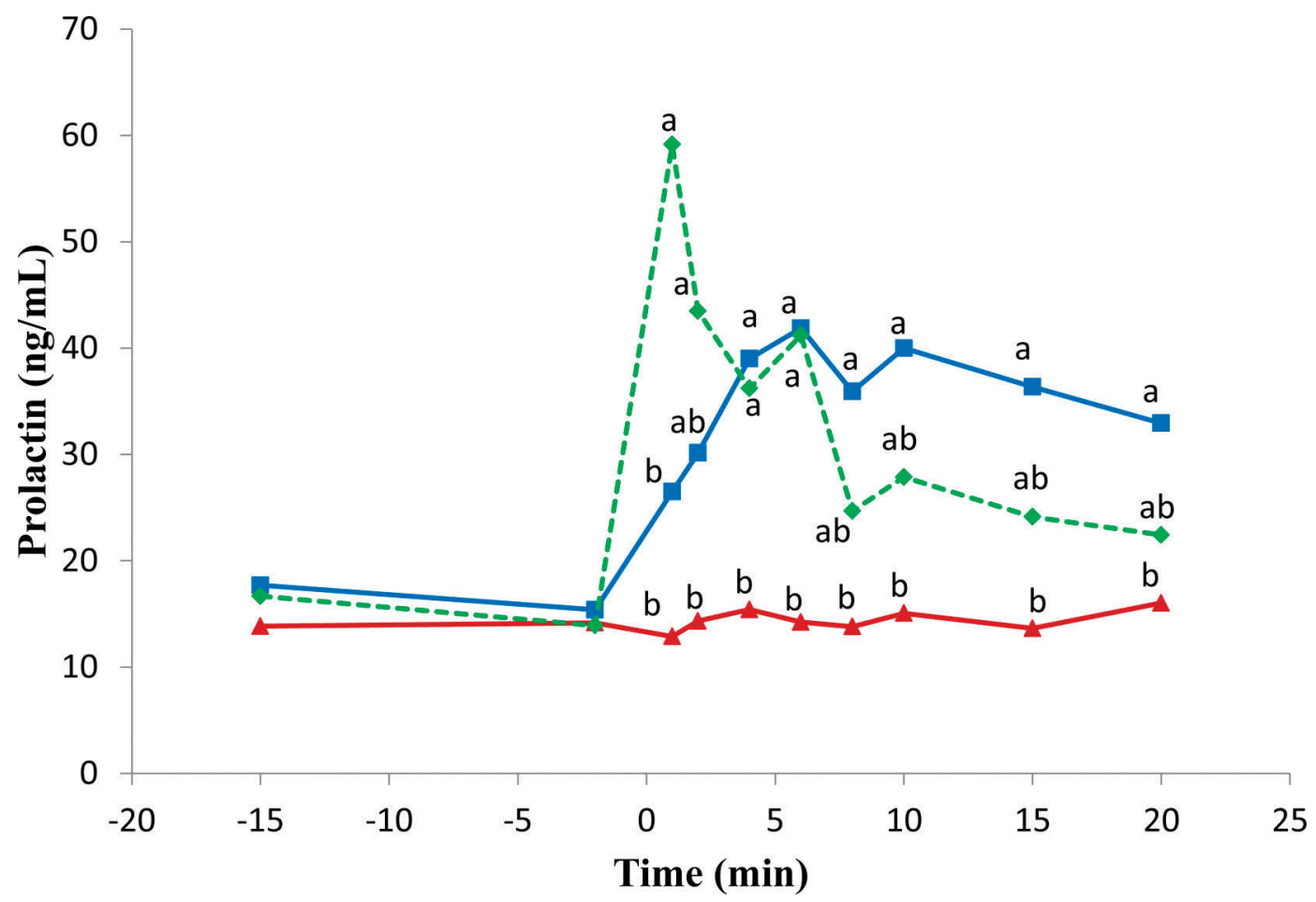

Figure 1. Blood prolactin concentration relative to milking-unit attachment in dairy cows injected daily with the vehicles (control; $\mathrm{n}=9$; 口), quinagolide ( $1 \mathrm{mg}$, injected i.m. $30 \mathrm{~min}$ before milking; $\mathrm{n}=8$; $\mathbf{\Delta})$, or quinagolide plus prolactin $(2 \mu \mathrm{g} / \mathrm{kg}$ of BW, injected i.v. at milking time; $\mathrm{n}=9 ;-)$. Data are presented as least squares means. Statistically different means during a specific time are indicated by different letters (a, b). Color version available online.

the PRL concentration was no longer greater $(P>$ $0.05)$ than the basal concentration at 8 min during $\mathrm{QN}$ PRL but was still elevated 20 min after milking-unit attachment during the control treatment.
Milk production was $3.2 \mathrm{~kg} / \mathrm{d}$ lower during QN $(P<$ 0.05; Table 2) than during the control treatment. Injections of PRL were not able to increase milk production above that level during QN injection only (contrast QN

Table 2. Milk yield and composition from dairy cows injected with the vehicles (control), quinagolide (QN), or quinagolide plus prolactin (QN$\mathrm{PRL})$ for $5 \mathrm{~d}(\mathrm{n}=26)^{1}$

\begin{tabular}{|c|c|c|c|c|c|c|c|}
\hline \multirow[b]{2}{*}{ Item } & \multicolumn{3}{|c|}{ Treatment } & \multirow[b]{2}{*}{ SEM } & \multirow[b]{2}{*}{$P$-value } & \multicolumn{2}{|c|}{ Contrast } \\
\hline & Control (C) & $\mathrm{QN}(\mathrm{Q})$ & QN-PRL (P) & & & $\mathrm{Q}$ vs. $\mathrm{P}$ & $\mathrm{C}$ vs. $\mathrm{Q}+\mathrm{P}$ \\
\hline Milk yield (kg/d) & $31.0^{\mathrm{a}}$ & $27.8^{\mathrm{b}}$ & $28.4^{\mathrm{b}}$ & 0.35 & 0.0001 & 0.20 & 0.0001 \\
\hline Fat $(\%)$ & $4.08^{\mathrm{a}}$ & $4.35^{\mathrm{b}}$ & $4.33^{\mathrm{b}}$ & 0.072 & 0.02 & 0.88 & 0.007 \\
\hline Fat $(g / d)$ & 1,240 & 1,195 & 1,220 & 21 & 0.31 & 0.40 & 0.19 \\
\hline Lactose $(\%)$ & 4.99 & 4.97 & 4.99 & 0.017 & 0.67 & 0.52 & 0.53 \\
\hline Lactose (g/d) & $1,540^{\mathrm{a}}$ & $1,380^{\mathrm{b}}$ & $1,410^{\mathrm{b}}$ & 17 & 0.0001 & 0.13 & 0.001 \\
\hline Protein $(\%)$ & $3.20^{\mathrm{a}}$ & $3.30^{\mathrm{b}}$ & $3.30^{\mathrm{b}}$ & 0.027 & 0.02 & 0.89 & 0.006 \\
\hline Protein $(\mathrm{g} / \mathrm{d})$ & $980^{\mathrm{a}}$ & $880^{\mathrm{b}}$ & $930^{\mathrm{ab}}$ & 19 & 0.007 & 0.09 & 0.004 \\
\hline Casein ( $\mathrm{g} / \mathrm{kg})$ & $25.3^{\mathrm{a}}$ & $26.5^{\mathrm{b}}$ & $26.5^{\mathrm{b}}$ & 0.28 & 0.008 & 0.99 & 0.003 \\
\hline Casein $(\mathrm{g} / \mathrm{d})$ & $774^{\mathrm{a}}$ & $728^{\mathrm{b}}$ & $745^{\mathrm{b}}$ & 10.2 & 0.02 & 0.24 & 0.007 \\
\hline Whey protein $(\mathrm{g} / \mathrm{kg})$ & $6.0^{\mathrm{a}}$ & $6.6^{\mathrm{b}}$ & $6.4^{\mathrm{b}}$ & 0.11 & 0.004 & 0.24 & 0.002 \\
\hline Whey protein $(\mathrm{g} / \mathrm{d})$ & 184 & 183 & 181 & 3.8 & 0.85 & 0.72 & 0.68 \\
\hline Casein:whey ratio & $4.29^{\mathrm{a}}$ & $4.04^{\mathrm{b}}$ & $4.17^{\mathrm{ab}}$ & 0.060 & 0.028 & 0.13 & 0.018 \\
\hline SCC (log) & 5.49 & 5.61 & 5.57 & 0.04 & 0.19 & 0.60 & 0.08 \\
\hline $\operatorname{ECM}(\mathrm{kg} / \mathrm{d})$ & $30.9^{\mathrm{a}}$ & $28.7^{\mathrm{b}}$ & $29.5^{\mathrm{b}}$ & 0.37 & 0.003 & 0.13 & 0.001 \\
\hline
\end{tabular}

$\overline{\mathrm{a}, \mathrm{b}}$ Letters indicate significant difference according to the treatments.

${ }^{1} \mathrm{QN}=1 \mathrm{mg}$ of quinagolide was injected i.m. twice a day $30 \mathrm{~min}$ before milking. PRL $=$ prolactin $2 \mu \mathrm{g} / \mathrm{kg}$ of BW was injected i.v. twice a day at milking time. 
vs. QN-PRL, $P=0.20$ ). The treatments did not significantly affect DMI $(P=0.18)$, which averaged 22.2 , 21.1 , and $21.2 \pm 0.46 \mathrm{~kg} / \mathrm{d}$ during the control, QN, and QN-PRL treatments, respectively.

Injections of $\mathrm{QN}$, alone or with $\mathrm{PRL}$, increased milk fat and protein contents $(P<0.01$; Table 2$)$ in comparison with the control treatment, whereas those contents were not affected by PRL injections (contrast QN vs. QN-PRL, $P>0.80$; Table 2). Neither lactose content nor fat yield was affected by the treatments. Milk protein yield was reduced by the QN treatment in comparison with the control treatment, and PRL tended to restore milk protein yield (contrast QN vs. QN-PRL, $P=0.09)$. Injections of $\mathrm{QN}$, alone or with PRL, reduced lactose yield $(P<0.001$; Table 2$)$.

Both casein content $(P=0.003)$ and whey protein content $(P=0.002$; Table 2$)$ were greater with $\mathrm{QN}$ injections (QN + QN-PRL) than during the control treatment. Despite the greater casein content, the casein yield was lower with $\mathrm{QN}$ injections than during the control treatment $(P=0.007)$. The treatments had no effect on whey protein yield $(P>0.1)$. The caseinto-whey protein ratio was lower $(P=0.018)$ with $\mathrm{QN}$ injections than during the control treatment, indicating that the inhibitory effect of QN was greater for casein than for whey protein. Injections of PRL did not affect casein or whey protein content in milk. Blood concentrations of NEFA, glucose, urea, IGF-1, and growth hormone were not affected by any of the treatments (Table 3). Blood lactose concentration tended $(P=$ 0.1 ) to be greater during the $\mathrm{QN}$ treatment than during QN-PRL.

The histological analyses showed that the percentage of PCNA-positive cells in mammary tissue tended to be lower during QN $(P=0.09)$ than during the control treatment (Figure 2). However, the percentage of PCNA-positive cells was greater during QN-PRL than during the control treatment $(P<0.05)$ or $\mathrm{QN}$ treatment $(P=0.001)$. The percentage of STAT5-positive cells was lower during $\mathrm{QN}(P<0.05)$ than during the control treatment (Figure 3 ). The percentage of STAT5-positive cells during QN-PRL was numerically intermediate between those of the control and QN treatments and did not differ from either of them $(P$ $>0.1$ ). The percentage of apoptotic cells detected by TUNEL assay was not affected by the treatments $(P=$ 0.48; data not shown).

Injections of $\mathrm{QN}$ increased the concentration of MEC in milk $(P=0.02)$ as well as the number of total $(P$ $=0.02)$, living $(P=0.03)$, and dead $(P=0.01) \mathrm{MEC}$ exfoliated into milk per day (Table 4 ). Injections of QN did not affect the viability of MEC purified from milk $(P>0.1)$, although viability was greater during the QN-PRL treatment than during QN $(P=0.01)$. A trend $(P=0.1)$ was observed for a decrease in the number of milk MEC exfoliated per day during the QNPRL treatment in comparison with during QN. The number of dead MEC exfoliated into milk was lower during the QN-PRL treatment than during $\mathrm{QN}(P=$ 0.01 ).

The mRNA levels of the majority of the genes analyzed by RT-qPCR in mammary tissue were not affected by the treatments (Table 5 ). The $B A X$ mRNA level was lower during the QN-PRL treatment than during QN $(P=0.01$; Table 5$)$. In the milk-purified MEC, the mRNA levels of both CSN3 and LALBA were lower during QN injections than during the control treatment $(P<0.05)$. However, expressions of these genes were intermediate in QN-PRL and did not differ from either the QN or control treatment (Table 5).

Pearson correlation coefficients were calculated between PRL AUC and the milk, milk cell, gene expression, and histological data. Positive correlations were observed between PRL AUC and the percentage of PCNA-positive cells $(\mathrm{r}=0.39, P=0.04)$ and the percentage of STAT5-positive cells $(\mathrm{r}=0.54, P=0.02)$. Negative correlations were observed between PRL AUC and milk whey protein content $(\mathrm{r}=-0.41, P=$

Table 3. Blood metabolite and hormone concentrations in cows injected with the vehicles (control), quinagolide (QN), or quinagolide plus prolactin $(\mathrm{QN}-\mathrm{PRL} ; \mathrm{n}=26)^{1}$

\begin{tabular}{|c|c|c|c|c|c|c|c|}
\hline Item & \multicolumn{3}{|c|}{ Treatment } & SEM & $P$-value & \multicolumn{2}{|c|}{ Contrast } \\
\hline NEFA $(\mathrm{m} M)$ & 147 & 179 & 166 & 14 & 0.33 & 0.55 & 0.17 \\
\hline Urea $(\mathrm{mg} / \mathrm{dL})$ & 31 & 31 & 28 & 2 & 0.34 & 0.28 & 0.37 \\
\hline Lactose $(\mathrm{mg} / \mathrm{L})$ & 20 & 24 & 19 & 2 & 0.25 & 0.10 & 0.70 \\
\hline IGF-1 (ng/mL) & 189 & 184 & 162 & 10 & 0.14 & 0.14 & 0.19 \\
\hline
\end{tabular}

${ }^{1} \mathrm{QN}=1 \mathrm{mg}$ of quinagolide was injected i.m. twice a day $30 \mathrm{~min}$ before milking. PRL $=$ prolactin at $2 \mu \mathrm{g} / \mathrm{kg}$ of $\mathrm{BW}$ was injected i.v. twice a day at milking time. For growth hormone $(\mathrm{GH})$, the average blood concentration during 15 min relative to milking-unit attachment was calculated. Blood samples were harvested after $4 \mathrm{~d}$ of injections. 
0.03 ) and $B$ cl2 gene expression $(r=-0.41, P=0.04)$. Pearson correlation coefficients were also determined between the percentage of STAT5-positive cells and the other data. A significant correlation was observed between STAT5-positive cells and milk lactose content (r $=0.49, P=0.05)$. Negative correlations were observed between STAT5-positive cells and MEC concentration in milk, the number of milk MEC exfoliated per day, and the number of living milk MEC exfoliated per day $(\mathrm{r}=-0.72, \mathrm{r}=-0.68$, and $\mathrm{r}=-0.55$, respectively, $P$ $<0.05)$.

\section{DISCUSSION}

As expected, the short-term treatment of dairy cows in mid-lactation with QN reduced PRL release at milking, as indicated by a very low AUC during the QN treatment. In association with this effect, milk pro-
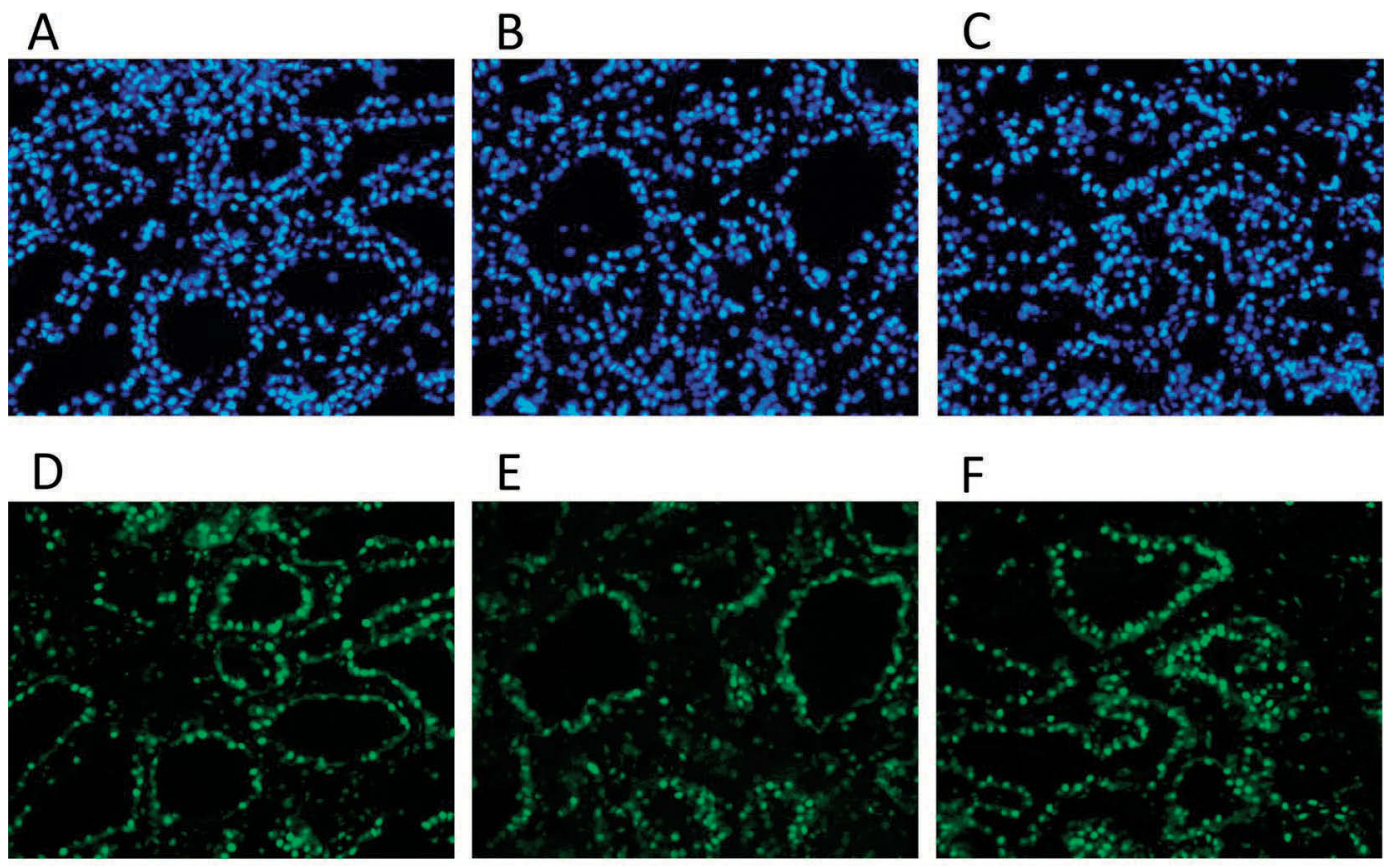

$\mathrm{F}$
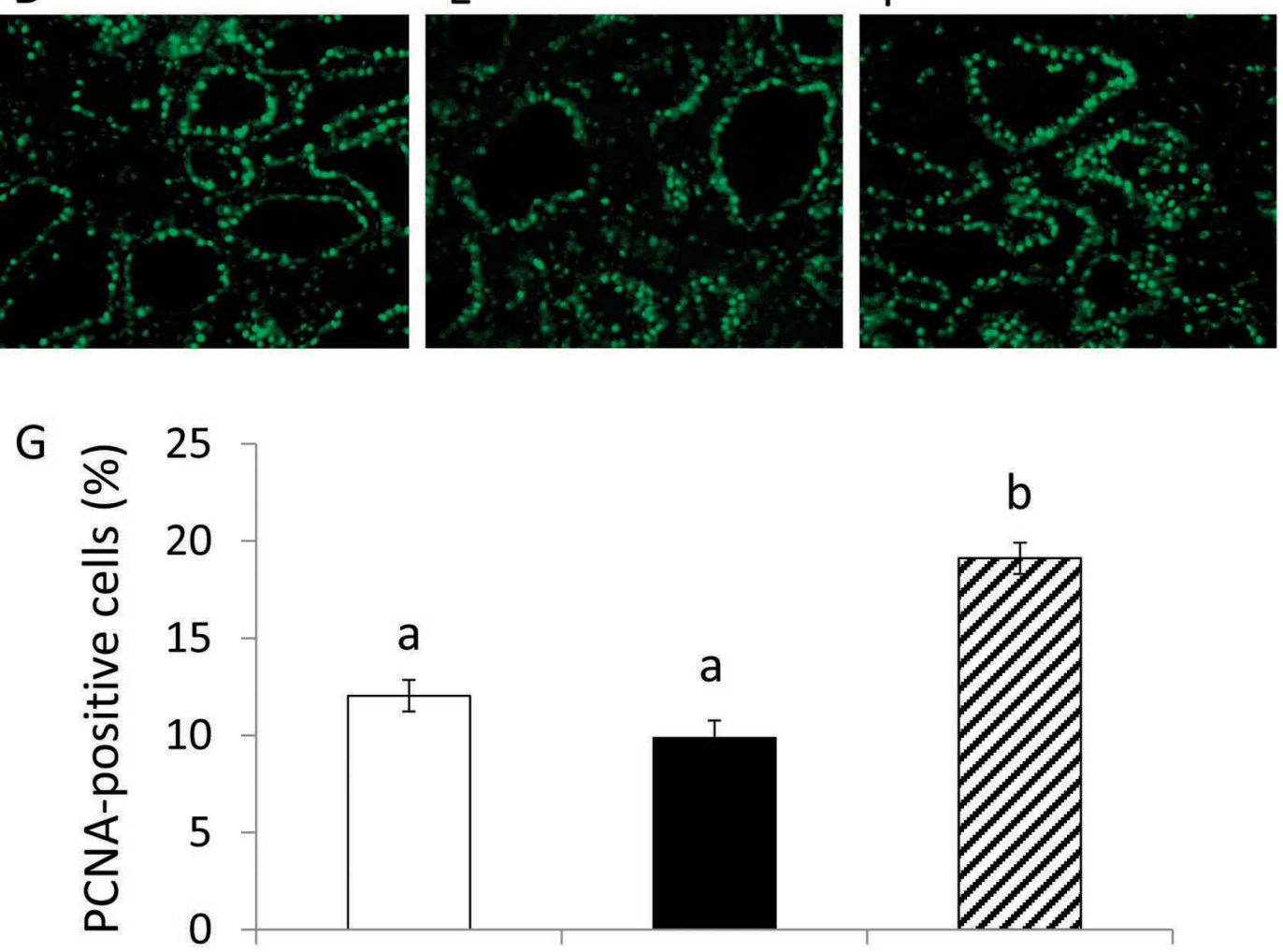

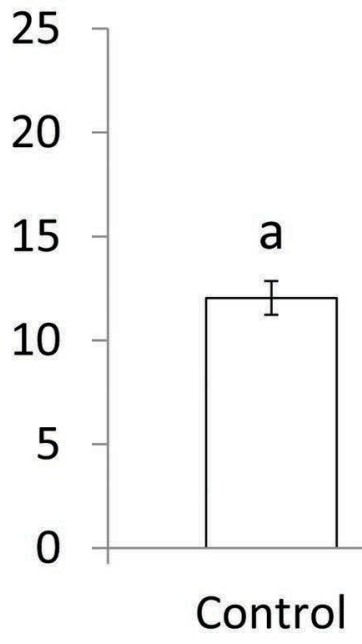

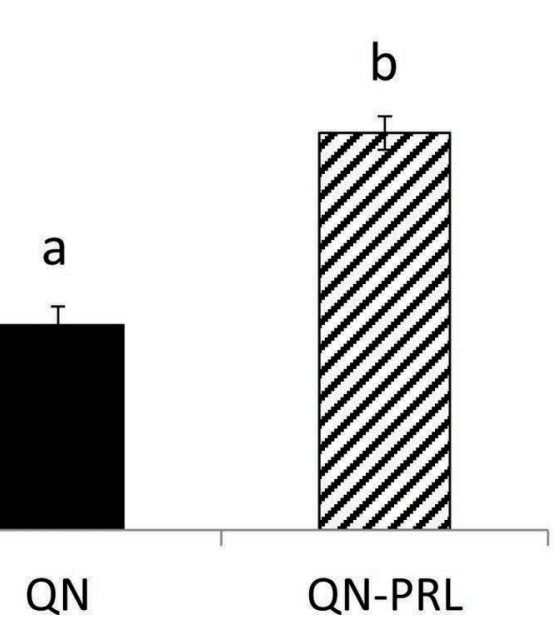

Figure 2. Detection of proliferating cell nuclear antigen (PCNA)-positive cells in mammary tissue from dairy cows injected daily with the vehicles (control), quinagolide (QN), or quinagolide plus prolactin (QN-PRL). The mammary tissue sections from the control (A, D), QN (B, E), and QN-PRL (C, F) cows were stained simultaneously with 4',6-diamidino-2-phenylindole (DAPI; A, B, C) and PCNA antibody (D, E, F). The micrographs present the sections obtained in mammary tissue from 1 representative cow (magnification $\times 200$ ). In panel $\mathrm{G}$, data are presented as least squares mean \pm standard error of the mean, and the letters $(\mathrm{a}, \mathrm{b})$ indicate significant differences according to the treatments. Color version available online. 

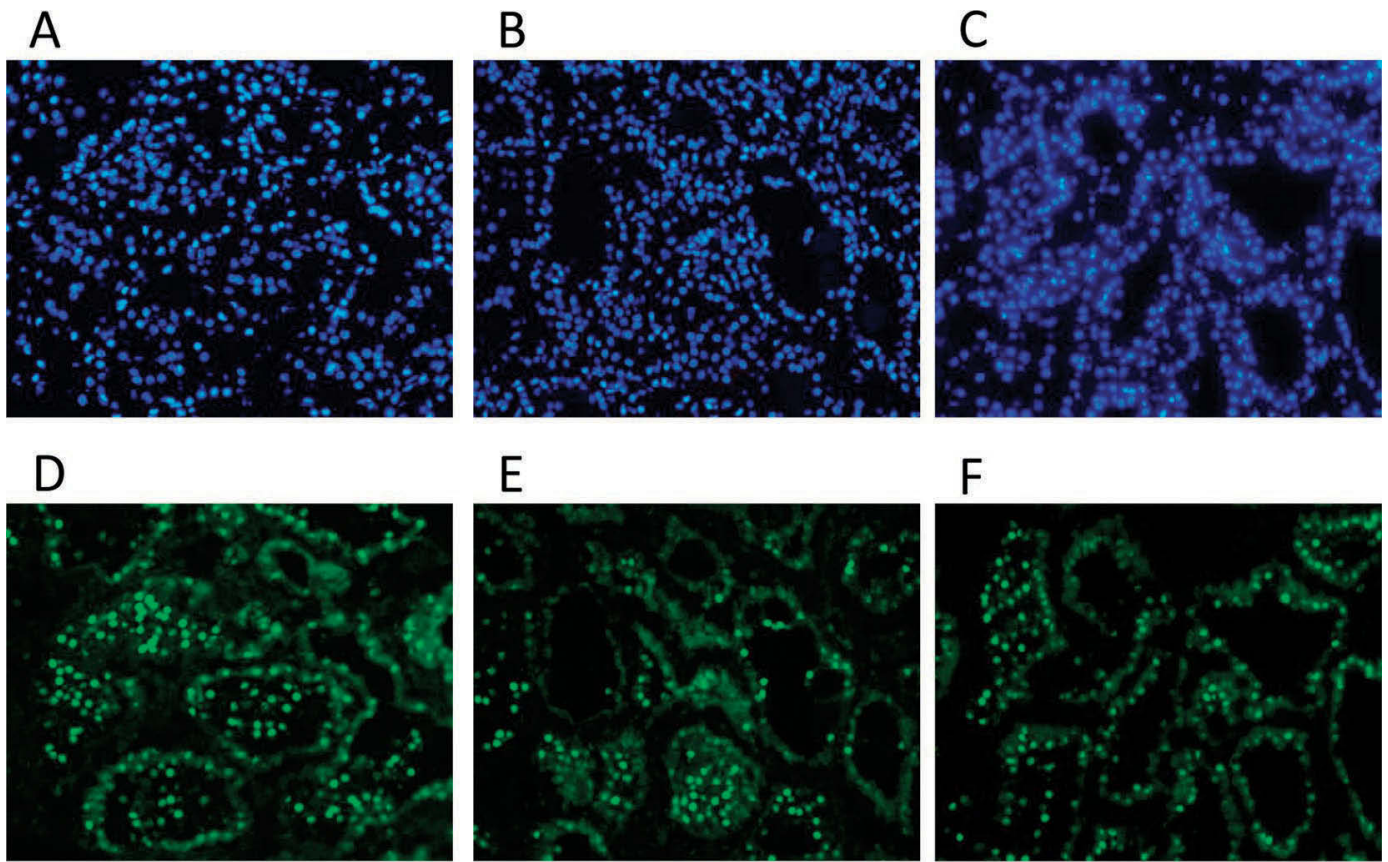

$\mathrm{F}$

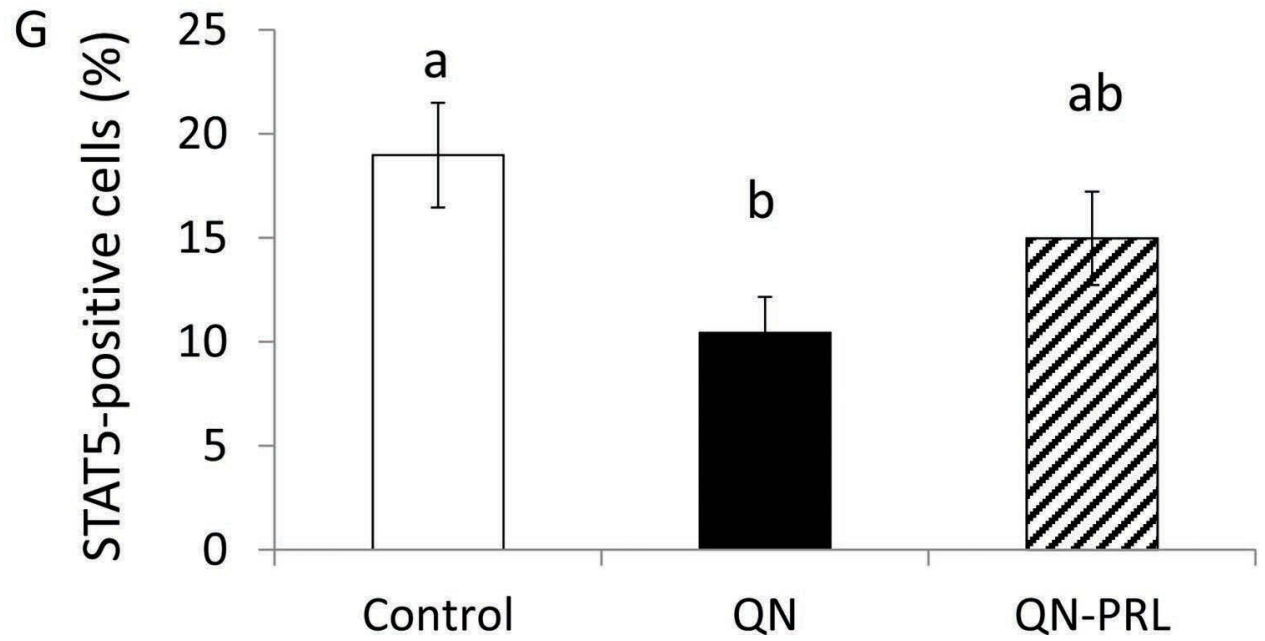

Figure 3. Detection of signal transducer and activator of transcription 5 (STAT5)-positive cells in mammary tissue from dairy cows injected daily with the vehicles (control), quinagolide (QN), or quinagolide plus prolactin (QN-PRL). The mammary tissue sections from the control (A D), QN (B, E), and QN-PRL (C, F) cows were stained simultaneously with 4',6-diamidino-2-phenylindole (DAPI; A, B, C) and STAT5 antibody $(\mathrm{D}, \mathrm{E}, \mathrm{F})$. The micrographs present the sections obtained in mammary tissue from 1 representative cow (magnification $\times 200)$. In panel $\mathrm{G}$, data are presented as least squares mean \pm standard error of the mean, and the letters $(\mathrm{a}, \mathrm{b})$ indicate significant differences according to the treatments. Color version available online.

duction was reduced by $10 \%$. In a previous long-term study, milk production was not affected by QN during the first few weeks of treatment but was reduced by 5.3 $\mathrm{kg} / \mathrm{d}(14 \%)$ during the last $4 \mathrm{wk}$ (Lacasse et al., 2011). In the present study, the setup of the experiment as a Latin square design and the higher dose used for the QN injections (2 vs. $1 \mathrm{mg} / \mathrm{d}$ ) may explain why the effect was already observed after $5 \mathrm{~d}$ of treatment, unlike in the previous study. The effect on milk yield was not associated with changes in DMI or blood metabolites. The rapid decrease in milk production during QN treatment and the fact that changes in DMI play a minor role in the decrease in milk yield during $\mathrm{QN}$ treatment were previously observed (Ollier et al., 2014).

In association with the reduction in milk production, the yields of lactose, protein, and casein were reduced by QN. These effects were accompanied by significant reductions in $C N S 3$ and $L A L B A$ mRNA levels observed 
Table 4. Concentration and viability of mammary epithelial cells (MEC) exfoliated into milk by dairy cows injected with the vehicles (control), quinagolide $(\mathrm{QN})$, or quinagolide plus prolactin (QN-PRL; $\mathrm{n}=26)^{1}$

\begin{tabular}{|c|c|c|c|c|c|c|c|}
\hline \multirow[b]{2}{*}{ Item } & \multicolumn{3}{|c|}{ Treatment } & \multirow[b]{2}{*}{ SEM } & \multirow[b]{2}{*}{$P$-value } & \multicolumn{2}{|c|}{ Contrast } \\
\hline & Control (C) & $\mathrm{QN}(\mathrm{Q})$ & QN-PRL (P) & & & $\mathrm{Q}$ vs. $\mathrm{P}$ & $\mathrm{C}$ vs. $\mathrm{Q}+\mathrm{P}$ \\
\hline Milk MEC concentration (cells/mL) & $7,000^{\mathrm{a}}$ & $11,400^{\mathrm{b}}$ & $9,600^{\mathrm{ab}}$ & 1,200 & 0.05 & 0.29 & 0.02 \\
\hline Milk MEC viability (\%) & $61.7^{\mathrm{ab}}$ & $52.6^{\mathrm{a}}$ & $69.2^{\mathrm{b}}$ & 3.9 & 0.03 & 0.01 & 0.85 \\
\hline Milk MEC exfoliation $\left(10^{6}\right.$ cells $\left./ \mathrm{d}\right)$ & $204^{\mathrm{a}}$ & $326^{\mathrm{b}}$ & $256^{\mathrm{ab}}$ & 29.4 & 0.03 & 0.10 & 0.02 \\
\hline Living MEC $\left(10^{6}\right.$ cells $\left./ \mathrm{d}\right)$ & $112^{\mathrm{a}}$ & $176^{\mathrm{b}}$ & $171^{\mathrm{ab}}$ & 22.2 & 0.08 & 0.87 & 0.03 \\
\hline Dead MEC $\left(10^{6}\right.$ cells $\left./ \mathrm{d}\right)$ & $92^{\mathrm{a}}$ & $150^{\mathrm{b}}$ & $85^{\mathrm{a}}$ & 15.1 & 0.01 & 0.01 & 0.16 \\
\hline
\end{tabular}

${ }_{\mathrm{a}, \mathrm{b}}$ Letters indicate significant difference according to the treatments.

${ }^{1}$ Milk samples were harvested after $4 \mathrm{~d}$ of injections. $\mathrm{QN}=1 \mathrm{mg}$ of quinagolide was injected i.m. twice a day 30 min before milking. PRL $=$ prolactin at $2 \mu \mathrm{g} / \mathrm{kg}$ of $\mathrm{BW}$ was injected i.v. twice a day at milking time.

in milk-purified MEC. The downregulation of $L A L B A$ gene expression may be involved in the lower lactose yield and milk production observed with the QN treatment. Indeed, $L A L B A$ encodes $\alpha$-lactalbumin, which is the coenzyme of lactose synthase, and because lactose is the major osmotic agent in milk, lactose affects the milk volume. The downregulation of milk protein gene expression with QN treatment was previously observed in bovine mammary tissue and in milk-purified MEC (Boutinaud et al., 2012). The effect of QN on milk protein transcripts could be due to the inhibition of milking-induced PRL release, because PRL is known to stimulate milk protein expression in bovine MEC (Choi et al., 1988; Stiening et al., 2008).

One way to demonstrate that the effects of QN treatment on the mammary gland are due to PRL inhibition is to evaluate the effect of QN on known PRL targets in mammary tissue. Thus, we evaluated the percentage of STAT5-positive cells in mammary tissue. According to Molenaar et al. (2000), only activated forms of STAT5 are located in the nucleus. Therefore, given that we counted only the nuclear forms of STAT5, our determination should correspond to the cells in which STAT5 was activated. The QN treatment reduced the percentage of STAT5-positive cells in mammary tissue. Moreover, a significant correlation was found between the amount of PRL released at milking (AUC) and the percentage of STAT5-positive cells. These results suggest that the effect of QN on mammary tissue is specific to PRL inhibition. The lower activation of STAT5 in mammary tissue with the QN treatment may have been responsible for the downregulation of $L A L B A$ and $C S N 3$ mRNA levels that was observed. This result is in agreement with the downregulation of $L A L B A$ observed in the mammary tissue of transgenic mouse, where STAT5 expression was repressed (Reichenstein

Table 5. $\log _{10}$ of target gene mRNA levels relative to PPIA mRNA levels in mammary tissue and in milk-purified mammary epithelial cells (MEC) of dairy cows injected daily with the vehicles (control), quinagolide $(\mathrm{QN})$, or quinagolide plus prolactin $(\mathrm{QN}-\mathrm{PRL} ; \mathrm{n}=26$ for mammary tissue samples; $\mathrm{n}=23$ for milk-purified MEC samples) ${ }^{1}$

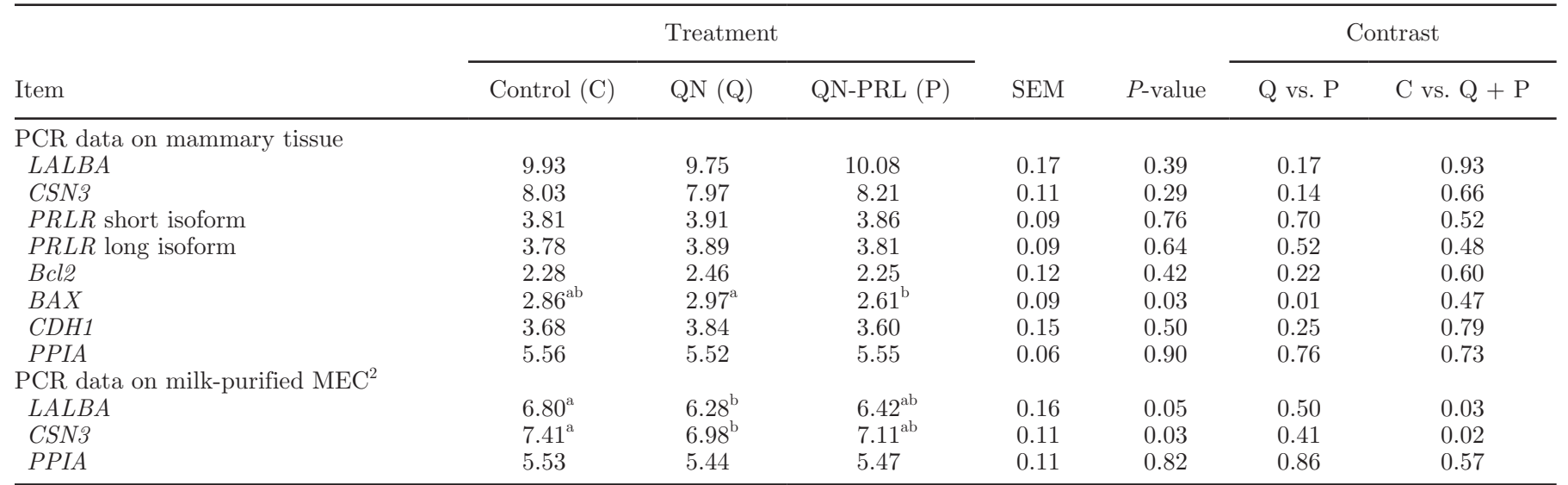

a,b Letters indicate significant difference according to the treatments.

${ }^{1}$ Milk samples were harvested after $4 \mathrm{~d}$ of injections, and mammary biopsies were taken after $5 \mathrm{~d}$ of injections. QN $=1 \mathrm{mg}$ of quinagolide was injected i.m. twice a day $30 \mathrm{~min}$ before milking. PRL $=$ prolactin at $2 \mu \mathrm{g} / \mathrm{kg}$ of BW was injected i.v. twice a day at milking time. PRLR $=$ prolactin receptor.

${ }^{2}$ Analyses were performed on the semi-absolute mRNA molecule number relative to PPIA multiplied by $10^{5}$ and $\log _{10}$-transformed. 
et al., 2011). The significant correlation observed between STAT5 and lactose content in our study suggests that the low activation of STAT5 by QN is responsible for the long-term reduction in milk lactose content in QN-treated cows (Lacasse et al., 2011). Thus, the effect of QN on STAT5 is further evidence that the reduction in milk yield during $\mathrm{QN}$ treatment is due to PRL inhibition.

To further demonstrate that the effect of QN treatment on mammary tissue is related to PRL inhibition, we injected cows with recombinant bovine PRL in addition to the QN treatment and observed whether the negative effect of QN on milk yield was reversed. The determination of the PRL AUC in the blood during the first $20 \mathrm{~min}$ following milking-unit attachment suggests that the amount of PRL released at milking was well mimicked by the amount of PRL that was administered. However, the conclusion might have been different for a longer sampling period, given that the PRL concentrations during the control treatment were still greater than those during the $\mathrm{QN}$ treatment at the end of the sampling period, whereas the PRL concentrations during the QN-PRL treatment were no longer different from those during the $\mathrm{QN}$ treatment $8 \mathrm{~min}$ after milking-unit attachment. Accordingly, the concentration of PRL returned to the basal concentration 40 min after milking-unit attachment (Lacasse and Ollier, 2015). This observation suggests that the dose used for PRL injections could not have been sufficient to mimic the entire endogenous release of PRL.

Injections of PRL at milking time in addition to the QN treatment were not sufficient to restore milk yield but tended to increase protein yield. These results are in accordance with previous studies in which PRL was injected into dairy cows (Plaut et al., 1987; Wall et al., 2006). In contrast with previous observations in dairy cows (Wall et al., 2006), PRL injections in our study did not significantly affect $L A L B A$ or $C N S 3$ mRNA levels, but their levels in milk-purified MEC showed intermediate values during the QN-PRL treatment in comparison with during the control and QN treatments. This was also the case for STAT5-positive cells in mammary tissue. The lack of a significant effect of PRL injections even in PRL-deprived animals could be due either to an insufficient dose of injected PRL or to a lower potency of recombinant bovine PRL in comparison with endogenous PRL, as previously discussed for sows (Farmer et al., 1999). Moreover, even though the endogenous PRL release at milking was mimicked by PRL injection, the kinetics of PRL in blood was different, with greater PRL peak concentration and shorter PRL exposure during the QN-PRL treatment in comparison with during the control treatment. A previous study showed that at high PRL concentra- tions, desensitization of the mammary gland occurred, presumably related to lower levels of PRLR that prevented any further responses in casein synthesis and mRNA levels and could cause the inhibition of both (Djiane et al., 1982). Thus, the injection of exogenous PRL or the kinetics of blood PRL after PRL injections could in part explain the absence of a milk response after PRL restoration.

Despite its lack of effect on MEC differentiation and milk yield, PRL injections did affect several indicators of MEC survival and proliferation. Our first result showing that PRL acts on cell proliferation in the mammary gland is that injections of $\mathrm{QN}$ tended to decrease the percentage of PCNA-positive cells in mammary tissue, whereas PRL injections increased it. These effects are in accordance with the known effects of PRL on the induction of MEC proliferation in bovine primary cultures (Olazabal et al., 2000) and with the significant reduction in PCNA-positive cells with longterm QN treatment (Boutinaud et al., 2012). However, our results are not in accordance with the absence of in vivo effects of bovine PRL injections on cell proliferation, as determined either by autoradiography or by thymidine incorporation in dairy cows (Wall et al., 2006). In the present study, the proliferative effect of exogenous PRL was detected when endogenous PRL was depleted via QN treatment. Thus, our results suggest that the proliferative effect of PRL could depend on the saturation of the PRLR. The limited ability of the mammary gland to respond to additional PRL due to saturation of the mammary gland binding site was previously suggested by Plaut et al. (1987).

In contrast with a previous long-term experiment involving several of the present authors (Boutinaud et al., 2012), short-term QN treatment in the present study did not increase the percentage of apoptotic cells in mammary tissue as measured by TUNEL assay. Similarly, PRL injections did not affect the percentage of apoptosis. However, PRL injections significantly downregulated the $B A X$ mRNA level in mammary tissue. This result suggests that PRL can inhibit apoptosis in bovine mammary tissue, as already observed in bovine explants (Accorsi et al., 2002) and in rat mammary tissue after in vivo PRL injections (Travers et al., 1996). This result also suggests that the anti-apoptotic effect of PRL in mammary tissue depends on the duration of the treatment.

In this experiment, we evaluated the variations in MEC exfoliation or MEC survival by examining the population of cells that were sloughed off into the milk after the manipulation of blood PRL concentrations. Injections of QN increased the number of MEC exfoliated daily into the milk, and this effect was partly reversed by PRL injections. Interestingly, QN increased 
the number of living and dead MEC exfoliated into the milk, whereas PRL reduced the number of dead MEC exfoliated into milk. A similar effect was observed during mammary gland involution, where an injection of cabergoline, another dopamine agonist, in dairy cows induced an increase in the MEC concentration in mammary secretions and a reduction in their viability (Boutinaud et al., 2013). In another recent experiment, more MEC were exfoliated into milk when the PRL concentration was reduced by a short-day photoperiod (Boutinaud et al., 2014). These results suggest that PRL could contribute to the maintenance of epithelium integrity by reducing the exfoliation and death rate of MEC. Accordingly, blood lactose, an indicator that usually increases when a loss of mammary epithelium integrity occurs, tended to be greater in the QN treatment than in the QN-PRL treatment.

\section{CONCLUSIONS}

The aim of this study was to assess the specific action of PRL in the mammary tissue of lactating dairy cows. Daily injections of QN reduced milking-induced PRL release and decreased milk, lactose protein, and casein production. Injections of PRL in QN-treated cows did not restore milk yield or milk protein mRNA levels but tended to increase protein yield. Despite their lack of effect on MEC differentiation and milk yield, PRL injections had significant effects on several indicators of MEC survival and proliferation, namely downregulation of the $B A X \mathrm{mRNA}$ level in mammary tissue, higher cell proliferation rate, and higher milk MEC survival. These results show that the effect of QN is likely a specific effect of PRL inhibition and support the assertion that PRL has a galactopoietic role in ruminants.

\section{ACKNOWLEDGMENTS}

The authors thank the team of the experimental farm at Méjusseaume (IEPL, INRA, Le Rheu, France) for taking care of the cows and assisting with the milk, plasma, and mammary biopsy sampling. We are also grateful to S. Marion, T. Le Mouël, and N. Huchet (INRA, Saint Gilles, France) for providing technical help and to L. Delaby (INRA) for assisting with the statistical analyses.

\section{REFERENCES}

Accorsi, P. A., B. Pacioni, C. Pezzi, M. Forni, D. J. Flint, and E. Seren. 2002. Role of prolactin, growth hormone and insulin-like growth factor 1 in mammary gland involution in the dairy cow. J. Dairy Sci. 85:507-513.
Andersen, C. L., J. L. Jensen, and T. F. Ørntoft. 2004. Normalization of real-time quantitative reverse transcription-PCR data: A model-based variance estimation approach to identify genes suited for normalization, applied to bladder and colon cancer data sets. Cancer Res. 64:5245-5250.

Ben Chedly, H., P. Lacasse, P.-G. Marnet, S. Wiart-Letort, L. Finot, and M. Boutinaud. 2009. Cell junction disruption after $36 \mathrm{~h}$ milk accumulation was associated with changes in mammary secretory tissue activity and dynamics in lactating dairy goats. J. Physiol. Pharmacol. 60(Suppl. 3):105-111.

Boutinaud, M., M. H. Ben Chedly, E. Delamaire, and J. GuinardFlament. 2008. Milking and feed restriction regulate transcripts of mammary epithelial cells purified from milk. J. Dairy Sci. 91:988998.

Boutinaud, M., A. Bondon, P. Debournoux, J. Couedon, M. Johan, A. Narcy, and C. Hurtaud. 2014. Daylength affects simultaneously mammary epithelium integrity and mammary epithelial cell exfoliation in milk. J. Anim. Sci. 92(E-Suppl. 2)/J. Dairy Sci. 97(ESuppl. 1):611.

Boutinaud, M., N. Isaka, A. Deflandre, E. Gandemer, P.-G. Marnet, F. Dessauge, and V. Lollivier. 2013. Prolactin-inhibitor cabergoline enhanced the mammary remodeling during drying-off in dairy cows. J. Anim. Sci. 91(E-Suppl. 2)/J. Dairy Sci. 96(E-Suppl. 1):151.

Boutinaud, M., and H. Jammes. 2004. Growth hormone increases Stat5 and Stat1 expression in lactating goat mammary gland: A specific effect compared to milking frequency. Domest. Anim. Endocrinol. 27:363-378.

Boutinaud, M., V. Lollivier, L. Finot, R. M. Bruckmaier, and P. Lacasse. 2012. Mammary cell activity and turnover in dairy cows treated with the prolactin-release inhibitor quinagolide and milked once daily. J. Dairy Sci. 95:177-187.

Boutinaud, M., J. H. Shand, M. A. Park, K. Phillips, J. Beattie, D. J. Flint, and G. J. Allan. 2004. A quantitative RT-PCR study of the mRNA expression profile of the IGF axis during mammary gland development. J. Mol. Endocrinol. 33:195-207.

Choi, Y. J., W. L. Keller, I. E. Berg, C. S. Park, and A. G. Mackinlay. 1988. Casein gene expression in bovine mammary gland. J. Dairy Sci. 71:2898-2903.

Cochran, W. G., and G. M. Cox. 1957. Experimental Designs. 2nd ed. Wiley, New York, NY.

Djiane, J., L.-M. Houdebine, and P. A. Kelly. 1982. Correlation between prolactin-receptor interaction, down-regulation of receptors, and stimulation of casein and deoxyribonucleic acid biosynthesis in rabbit mammary gland explants. Endocrinology 110:791-795.

Farmer, C., M. T. Sorensen, S. Robert, and D. Petitclerc. 1999. Administering exogenous porcine prolactin to lactating sows: Milk yield, mammary gland composition, and endocrine and behavioral responses. J. Anim. Sci. 77:1851-1859.

Farr, V. C., K. Stelwagen, L. R. Cate, A. J. Molenaar, T. B. McFadden, and S. R. Davis. 1996. An improved method for the routine biopsy of bovine mammary tissue. J. Dairy Sci. 79:543-549.

Groner, B., and F. Gouilleux. 1995. Prolactin-mediated gene activation in mammary epithelial cells. Curr. Opin. Genet. Dev. 5:587-594.

Hammon, H., and J. W. Blum. 1997. The somatotropic axis in neonatal calves can be modulated by nutrition, growth hormone, and Long-R3-IGF-I. Am. J. Physiol. 273:E130-E138.

INRA. 2007. Nutrition of Cattle, Sheep and Goats: Animal NeedsValues of Feeds. Quae Editions, Paris, France.

Knight, C. H. 2001. Overview of prolactin's role in farm animal lactation. Livest. Prod. Sci. 70:87-93.

Koprowski, J. A., and H. A. Tucker. 1973. Serum prolactin during various physiological states and its relationship to milk production in the bovine. Endocrinology 92:1480-1487.

Lacasse, P., V. Lollivier, R. M. Bruckmaier, Y. R. Boisclair, G. F. Wagner, and M. Boutinaud. 2011. Effect of the prolactin-release inhibitor quinagolide on lactating dairy cows. J. Dairy Sci. 94:1302-1309.

Lacasse, P., and S. Ollier. 2015. The dopamine antagonist domperidone increases prolactin concentration and enhances milk pro- 
duction in dairy cows. J. Dairy Sci. 98:7856-7864. http://dx.doi. org/10.3168/jds.2015-9865.

Molenaar, A. J., T. T. Wheeler, and M. R. Grigor. 2000. Nuclear localisation of the transcription factor Stat5b is associated with ovine milk protein gene expression during lactation but not during late pregnancy or forced weaning. Histochem. J. 32:265-274.

Olazabal, I., J. Muñoz, S. Ogueta, E. Obregón, and J. P. García-Ruiz. 2000. Prolactin (PRL)-PRL receptor system increases cell proliferation involving JNK (c-Jun amino terminal kinase) and AP-1 activation: Inhibition by glucocorticoids. Mol. Endocrinol. 14:564-575.

Ollier, S., X. Zhao, and P. Lacasse. 2014. Effects of feed restriction and prolactin-release inhibition at drying off on metabolism and mammary gland involution in cows. J. Dairy Sci. 97:4942-4954.

Plaut, K., D. E. Bauman, N. Agergaard, and R. M. Akers. 1987. Effect of exogenous prolactin administration on lactational performance of dairy cows. Domest. Anim. Endocrinol. 4:279-290.

Reichenstein, M., G. Rauner, and I. Barash. 2011. Conditional repression of STAT5 expression during lactation reveals its exclusive roles in mammary gland morphology, milk-protein gene expression, and neonate growth. Mol. Reprod. Dev. 78:585-596.

Riley, L. G., M. Gardiner-Garden, P. C. Thomson, P. C. Wynn, P. Williamson, H. W. Raadsma, and P. A. Sheehy. 2010. The influence of extracellular matrix and prolactin on global gene expres- sion profiles of primary bovine mammary epithelial cells in vitro. Anim. Genet. 41:55-63.

Stiening, C. M., J. B. Hoying, M. B. Abdallah, A. M. Hoying, R. Pandey, K. Greer, and R. J. Collier. 2008. The effects of endocrine and mechanical stimulation on stage I lactogenesis in bovine mammary epithelial cells. J. Dairy Sci. 91:1053-1066.

Suard, Y. M. L., M.-T. Haeuptle, E. Farinon, and J.-P. Kraehenbuhl. 1983. Cell proliferation and milk protein gene expression in rabbit mammary cell cultures. J. Cell Biol. 96:1435-1442.

Travers, M. T., M. C. Barber, E. Tonner, L. Quarrie, C. J. Wilde, and D. J. Flint. 1996. The role of prolactin and growth hormone in the regulation of casein gene expression and mammary cell survival: Relationships to milk synthesis and secretion. Endocrinology 137:1530-1539.

Vandesompele, J., K. De Preter, F. Pattyn, B. Poppe, N. Van Roy, A. De Paepe, and F. Speleman. 2002. Accurate normalization of real-time quantitative RT-PCR data by geometric averaging of multiple internal control genes. Genome Biol. 3:RESEARCH0034.

Wall, E. H., H. M. Crawford, S. E. Ellis, G. E. Dahl, and T. B. McFadden. 2006. Mammary response to exogenous prolactin or frequent milking during early lactation in dairy cows. J. Dairy Sci. 89:4640-4648. 